苗を用いたサツマイモ立枯病抵抗性室内検定法の改良

小林有紀 ${ }^{1)}$ ・高田明子 2) 岡田吉弘 ${ }^{3)}$ ・ 小柳敦史 ${ }^{1)}$ ・ 小林 晃 ${ }^{1)}$

1) 農研機構九州沖縄農業研究センター, 宮崎県都城市, 干 885-0091

2) 農研機構本部, 茨城県つくば市, 干 305-8517

3) 農研機構九州沖縄農業研究センタ一, 沖縄県系満市, 干 901-0336

\title{
Improvement of laboratory evaluating method for soil rot resistance in sweetpotato using vine cutting
}

Yuki O. Kobayashi' ${ }^{1)}$, Akiko Takada ${ }^{2)}$, Yoshihiro Okada ${ }^{3)}$, Atsushi Oyanagi ${ }^{1)}$ and Akira Kobayashi ${ }^{1)}$

1) Kyushu Okinawa Agricultural Research Center, NARO, Miyakonojo, Miyazaki 885-0091, Japan

${ }^{2)}$ Headquarters, NARO, Tsukuba, Ibaraki 305-8517, Japan

3) Kyushu Okinawa Agricultural Research Center, NARO, Itoman, Okinawa 901-0336, Japan

キーワード

サッマイモ立枯病, 抵抗性, 室内検定, 苗

\section{緒 言}

サッマイモ立枯病は，土壤中に生息する放線菌 Streptomyces ipomoeae (Person and Martin) Waksman and Henrici の感染により発生する土壌伝染性病害である。本 菌に污染された畑にサッマイモ[Ipomoea batatas (L.) Lam.]の苗を植え付けると, 菌系が細根の表皮細胞の細 胞壁を貫通あるいは表皮細胞の接合部から侵入して根を 腐らせるため（Clark and Matthews 1987），植え付け 2 週 間後頃から苗の葉色が黄色ないし紫紅色を帯び，次第に 生育不良となり，発病が著しい場合には枯死することも ある。また, 地下部の茥や, 収穫時の塊根にも黒褐色の 病斑を生じ, 塊根の品質低下をもたらす (Clark and Moyer 1988, Locci 1994, Loria et al. 1997). 本病は, 全国各地の サッマイモ栽培地帯で発生が認められているが（鈴井 1987), 化学農薬を用いた土壤消毒の他に有効な防除技術 は確立されておらず，抵抗性品種の育成が望まれている (Clark and Moyer 1988).

抵抗性品種を育成するためには，立枯病抵抗性の評価 に基づき育種選抜を進める必要があるが, 現在, サッマ イモ品種・系統の立枯病抵抗性は, 立枯病自然発生圃場 または人工污染圃場にサッマイモ苗を植え付け 2 ケ間

編集委員 : 片山健二

2017 年 11 月 29 日受領 2018 年 2 月 27 日受理

2018 年 4 月 3 日 J-STAGE 早期公開

Correspondence: kobajr@affrc.go.jp
栽培した後, 茥および根の病徵, 蔓の伸長状況を調査す ることにより評価している（藏之内ら 2014）。しかし， 圃場では, 年による気象変動の他, 土壌中の病原菌量の 偏りなどの影響を受けて発病が安定せず，同一圃場に抒 いても場所によって発病程度に大きな差が生じることが ある（藏之内ら 2014）。 また，抵抗性検定を行らための 立枯病自然発生圃場の確保や人工污染圃場の養成も容易 ではなく，圃場では，適する条件下での試験は年に 1 度 しか行えないことも問題点として挙げられる. そのため, 抵抗性を安定して評価することのできる簡易な室内検定 法の開発が望まれている.

室内検定法は，これまでにいくつかの報告がある. Moyer et al. （1984）は，立枯病菌污染砂を詰めたポット にサッマイモ苗を植えて温室で 10 週間栽培し, 根や塊根 の壊死割合に基づいて抵抗性を評価したが，検定に 2 ケ 月以上を要することが課題である. 一方, 井内ら（2005） は, サツマイモの葉を除いた約 $3 \mathrm{~cm}$ の茥断片を立枯病菌 眯濁液に浸漬した後, バーミキュライトに插して $30^{\circ} \mathrm{C}$ で7日間培養し, 生じた病斑数に基づいて抵抗性を評価 する検定法を考案したが，培養中に茎断片が腐敗してし まう確率が高いことを問題としている。 また，高野ら （2006）は，立枯病多発生圃場から採取した土壤を詰めた $200 \mathrm{ml}$ のスチロールカップにサッマイモ苗を植え付けた 後, 水温 $30 \sim 35^{\circ} \mathrm{C}$ の恒温槽にカップを設置して 3 週間 栽培し，根执よび茎の褐変程度に基づいて抵抗性を評価 した。しかし, 土壤中の立枯病菌数が不明であること, また, 週に 2 3 回カップの重量を測定して減量分に応じ 
た水補給をしなければならないため労力がかかり，1回 の検定に供試できる個体数が限られてしまらことが問題 と考兄られた，そこで，主に高野ら（2006）の方法を参 考にして，こ机ら問題点を解決でき，通年で試験をする ことのできる室内検定法の確立を試みるとともに，苗の 形質が立枯病発病程度に及淁影響についても検討した。

\section{材料および方法}

これまでの戋場検定の結果（藏之内ら 2014）から立枯 病抵抗性程度が異なることが分かっているサッマイモ 4 品種 1 系統, 「90IDN-47」(強),「ベニアズマ」(やや強), 「ベニコマチ」(やや弱),「高系 14 号」(弱),「パープル スイートロード」(弱) を供試した。黒ボク土抢よび水は けの良い火山灰土の日向土, 牛糞堆肥をそれ艺れ $3: 6$ : 1 で混合した栽培用土を深型 5 号ポットに詰め, これら 品種・系統の種イモを 2015 年 11 月（ポット (1)， 2016 年 3 月（ポット (2)，11月（ポット(3) に植兄付けた. 九州沖縄農業研究センタ一都城研究拠点の温室で, 16 時 間日長, 明期 $28^{\circ} \mathrm{C} /$ 暗期 $22^{\circ} \mathrm{C}(2015$ 年 12 月下旬から 2016 年 5 月中旬までの期間は $\left.24^{\circ} \mathrm{C} / 20^{\circ} \mathrm{C}\right)$ の条件下, 適宜灌 水しながら育苗した. 育苗中, 3 週間毎に 1 鉢当たり $0.6 \mathrm{~g}$ の硫安を追肥した．苗は基部から 1２節を残して繰り返 し採取し, $33 \mathrm{~cm}$ 以上の長い苗については, 茎頂基部か ら $25 \mathrm{~cm}$ を切断して苗を調整し, 試験に供試した. 採苗 時には, 採取した苗の茎の長さおよび節数を測定し, 調 整後の苗については，插苗の際に培土に埋没する下部 $10 \mathrm{~cm}$ の領域に含ま机る節数とその中央位置の太さを計 測した，茎の太さは，荎を楕円と仮定し，長径と短径を 測定して断面積を算出した.

サッマイモ立枯病菌は, 2011 年に沖縄県国頭郡本部町 の立枯病発生戋場から分離し, イースト・スターチ斜面 培地（1\%可溶性でんぷん， $0.2 \%$ Bacto $^{\mathrm{TM}}$ Yeast Extract, $1.5 \%$ 寒天）で数回継代した TA- 5 株を供試した。接種源 の調製は以下のように行った，TA-5 株を酵母エキス・グ ルコース液体培地 $\left(1 \%\right.$ Bacto $^{\mathrm{TM}}$ Yeast Extract, $1 \%$ グルコー ス, $\mathrm{pH} 7.2)$ 飞接種し, $30^{\circ} \mathrm{C}, 120 \mathrm{rpm}$ で 4 日間振とら培 養した. $10,600 \times \mathrm{g}$ で 5 分間遠心分離し，得られた菌体を 滅菌水に懸濁した，培地成分を除去するために再度遠心 分離した後, 得ら水た菌体に 9 倍量 $(\mathrm{w} / \mathrm{w})$ の滅菌水を 加え, ポッター型ホモジナイザーを用いて菌体が均一に 分散するまで磨砕した。懸濁液を隇菌水で $10 \sim 10^{5}$ まで 10 倍段階希釈したものを接種源とした。 $10^{3}$ 倍拈よび $10^{4}$ 倍希釈の接種源をそれぞれ $0.1 \mathrm{ml}$ ずつ直径 $9 \mathrm{~cm}$ の イースト・スターチ平板培地に塗布し, $30^{\circ} \mathrm{C} て ゙ 1$ 週間培 養後, 出現したコロニー数を計測し, 接種源と接種区培 土に含まれる立枯病菌数を算出した。

サッマイモ苗（11.4～135.8 cm）を採取し，前述の通り 苗長を調整し，上位完全展開葉 3 枚を残して下葉を切除 した、ポリプロピレン製 $50 \mathrm{ml}$ 遠沈管に苗を插した後, $105^{\circ} \mathrm{C}$ で 1 日間乾熱滅菌した培土（バーミキュライト) を 1 本当たり約 $6.5 \mathrm{~g}$ 詰め, 蒸留水を $20 \mathrm{ml}$ ずつ灌水し た. 培土の温度を $30 \pm 1{ }^{\circ} \mathrm{C}$ に保つため, 実験室内に設置 した温水槽の温水に遠沈管の下部が $7 \mathrm{~cm}$ 程度浸るよう 配置した（図 1A，B）。 8 9 月は自然光，10〜2月は木 ワイトシリカ電球（LW100V38W55, アサヒ）で補光し 16 時間日長で養成した。翌日， $10 \sim 10^{5}$ 倍希釈の立枯病 菌懸濁液および対照には蒸留水を $10 \mathrm{ml}$ ずつ培土に接種 し, その 3 日後に $1 / 2000$ 倍希釈の八イポネックス観葉植 物液（N：P : K=10:3:3）を $15 \mathrm{ml}$ ずつ灌注した。以 降は, 培土が乾燥し一部の遠沈管が浮いた時に全ての遠 沈管に対し, 液肥灌注から 1 週間未満であれば蒸留水

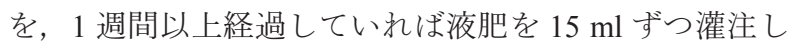
た。栽培期間中は, 苗の地際部付近にデータロガー （TR-74Ui，ティアンドディ）を設置し，15 分毎に温度と 湿度を測定した。

接種から 2 週間後に植物体の地下部を洗浄し, 茎㧊よ び根の発病を, 黒変・腐敗面積に基づいて茎は 6 段階 $(0$ : なし，1:20\%未満， $2: 20 \%$ 以上 $40 \%$ 未満，3:40\%以上 $60 \%$ 未満, $4: 60 \%$ 以上 $80 \%$ 未満, $5: 80 \%$ 以上), 根は 7 段階（0５ は茎と同じ， 6 : 茎頂の黄化・枯死）の発病 指数で評価し，それらを加算した総合発病程度を個体毎 に算出した。図 $1 \mathrm{C}$ に, 各発病指数区分に該当する個体 の例を示す.

立枯病菌の適切な接種濃度を決定するため, 抵抗性系 統「90IDN-47」と感受性品種「高系 14 号」の苗を 1 区 当たり $4 \sim 5$ 本供試して, 接種源の希釈倍率と発病程度の 関係を調べた。また，4品種 1 系統を用いた検定を，1試

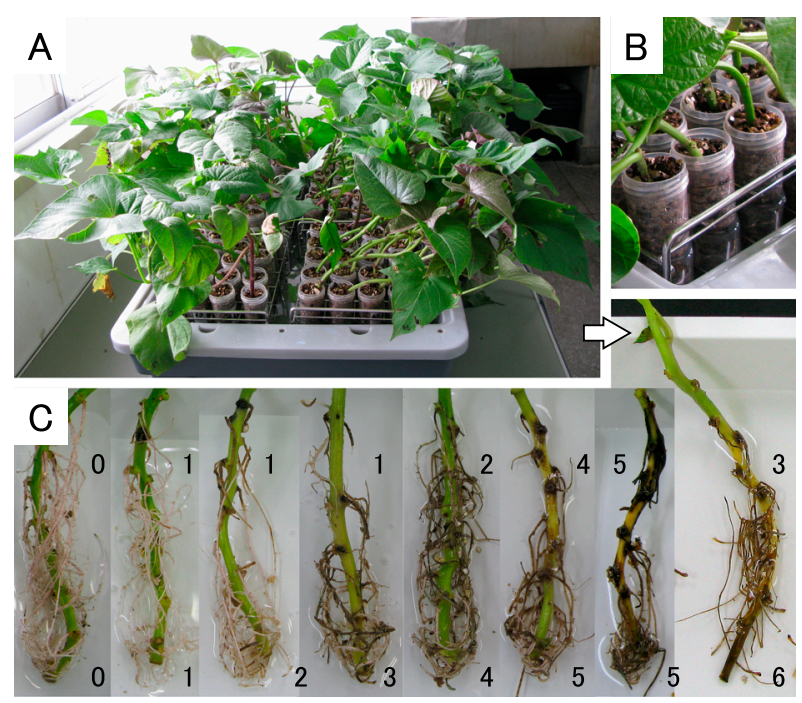

図 1. 立枯病抵抗性室内検定の様子.

ポリプロピレン製 $50 \mathrm{ml}$ 遠沈管にサッマイモ苗を挿した 後, バーミキュライトを詰め, 立枯病菌懸濁液を接種し, 温水槽 $\left(30 \pm 1{ }^{\circ} \mathrm{C}\right)$ に浸漬して 2 週間栽培した. $\mathrm{A}$ ：全体, $\mathrm{B}$ : 挿苗部位の拡大, $\mathrm{C}$ : 各発病指数区分に該当する個体 の例. 各数值は, 上段は茎, 下段は根の発病指数を示す. 矢印は黄化した茎頂. 
験当たり 3〜18 本の苗を供試して，秋期（試験 1）およ び冬期（試験 2), 夏期（試験 3）に行った。接種源濃度 を決定する試験における 1 品種 1 系統間の総合発病程度 の差異と, 試験 1 亿おける種イモの植え付け時期が異な る個体間の総合発病程度の差異は, 統計ソフトウェア $\mathrm{JMP}^{\circledR} 12$ (SAS Institute）を用いて数值を Box-Cox 変換し た後, $t$ 検定を行って評価した。試験 $1 \sim 3$ に抢ける総合 発病程度の品種・系統間差異は, Box-Cox 变換後に一元 配置分散分析と Tukey-Kramer の HSD 検定を行って評価 した。 また, 試験 1 3 亿拈ける総合発病程度と藏之内ら

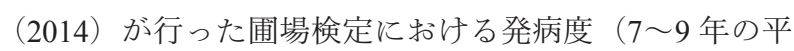
均值）との関係は, Box-Cox 変換後に積率相関係数を用 いて評価した。一方，苗の立枯病発病程度を変動させる 可能性がある 4 形質 (採取した苗の茎の長さおよび節数, ならびに長さを調整した苗の茎の太さ掞よび土中埋没節 数) と発病程度との関係は, 外孔值や分布の歪文に対し て感受性の低いSpearman の順位相関係数を用いて評価 した.

\section{結果および考察}

\section{1. 立枯病菌の接種濃度と発病程度}

2016 年 9 月に実施した本試験期間中の平均気温は $28.0^{\circ} \mathrm{C}$, 平均湿度は $71.9 \%$ であった. ポット(1)特よびポッ ト (2)から採取した抵抗性系統「90IDN-47」（長さ13.4〜 $32.3 \mathrm{~cm}$ ) 抒よび感受性品種「高系 14 号」（長さ11.4 $25.0 \mathrm{~cm}$ ）の苗に, 希釈倍率の異なる立枯病菌懸濁液を接 種した結果, $10 \sim 10^{4}$ 倍希釈液を接種した時に, 両品種・ 系統の総合発病程度に有意な差異が認められた（図 2). 発病程度の差の大きさや, 必要量の接種源を調整する労 力を考慮すると, 各品種・系統の立枯病抵抗性程度を判 別する検定には， $10^{2} \sim 10^{3}$ 倍希釈の立枯病菌懸濁液を接 種源として用いるのが適当であると考兄られた. $10^{2}$ およ び $10^{3}$ 倍希釈液を接種した時の培土中の立枯病菌数は, それぞれ $1.9 \times 10^{5}$ および $1.9 \times 10^{4} \mathrm{CFU}$ (colony-forming unit ; コロニー形成単位) $/ \mathrm{g}$ 乾土であった.

\section{4 品種 1 系統の立枯病発病程度}

立枯病抵抗性程度の異なる 4 品種 1 系統を供試して 行った 3 回の試験について, 試験実施時の各種条件を表 1 飞示す。

秋期に行った試験 1 では，ポット(1)拉よびポット (2)か ら採取した苗を供試したが，供試苗数が多かった「高系 14 号」と「90IDN-47」について統計解析を行ったとこ 万, 「高系 14 号」の総合発病程度はポット (1)由来苗 $(n$ =8）は $5.8 \pm 0.5$ ，ポット(2)由来苗 $(n=12)$ は $4.2 \pm 0.3$ で あり， $5 \%$ 水準で有意な差異が認められた。また， 「90IDN-47」の総合発病程度においても, ポット (1)由来 苗 $(n=8)$ は $2.0 \pm 0.3$, ポット (2)由来苗 $(n=16)$ は 1.3 \pm 0.1 であり, $1 \%$ 水準で有意な差異が認めら机た。.苗床

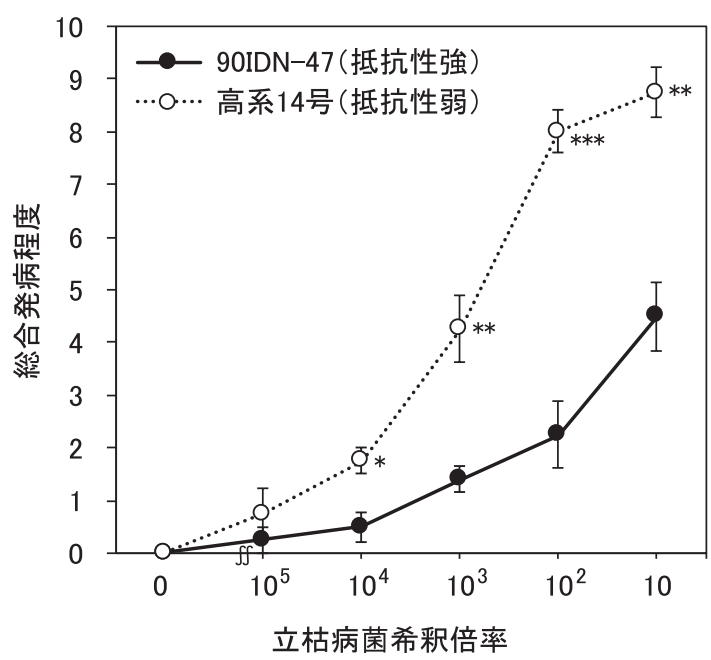

図 2. 室内検定法における立枯病菌の接種濃度と発病程度との関 係.

立枯病抵抗性程度が異なるサッマイモ 1 品種 1 系統に, 10 倍段階希釈した立枯病菌政濁液を接種して 2 週間栽培し た. 発病程度は, 黒変・腐敗面積に基づいて, 茎は 6 段 階, 根は7 段階に区分した発病指数で評価し，それらを加 算した総合発病程度を平均值 す. 各希釈段階に执いて，*は $5 \%$ 水準，**は $1 \%$ 水準，*** は $0.1 \%$ 水準で両品種・系統の総合発病程度に有意差があ ることを示す ( $t$ 検定).

で育てたサッマイモの苗は通常 5 6 回採苗するが, 2 4 番苗が良質で 5 番苗以降は繊維が増えて品質が劣化す る(日本いも類研究会 2009)。ポットで栽培した苗は伸 長したものから順次採取して試験に供試していたため, それらが何番苗にあたるのかは分からないが，採苗を繰 り返すことによる苗質の劣化が発病程度に差異を生じた 可能性が考兄られる，そこで，できるだけ苗質を揃える ため, 全体として供試数が多かったポット(2)由来の苗の 夕で 4 品種 1 系統の発病程度を比較した結果, 抵抗性強 の「90IDN-47」打よびやや強の「ベニアズマ」は，抵抗 性弱の「パープルスイートロード」拉よび「高系 14 号」 よりも有意に低い值を示した（図 3)。「90IDN-47」は抵 抗性がやや弱の「ベニコマチ」よりも有意に低い值を示 したが,「ベニアズマ」と「ベニコマチ」との間には有意 差は認められなかった。

冬期に行った試験 2 では, 植物体を温水槽ごと厚手の ビニールで覆って保温したため, 高湿度条件下での栽培 となった（表 1)。1 $10^{2}$ 倍希釈の立枯病菌懸濁液を接種し た培土の立枯病菌数は試験 1 と同程度となったが（表 1), 全品種・系統とも, 試験 1 よりも発病が高まった（図 3). 立枯病は乾燥条件下で発生し易い病害であるため, 立枯病発生戋場の土を用いた高野ら（2006）の室内検定 法では, 苗の活着後は土壤がやや乾燥状態になるよら水 管理を行っている，本試験では，高湿度条件のため培土 が乾燥せず，栽培期間全体を通じて試験 1 よりも湿潤な 傾向にあったが，発病程度は試験 1 よりも高かった。吉 
表 1. 立枯病抵抗性室内検定実施時の各種条件

\begin{tabular}{ccccccc}
\hline \hline 試験番号 & 実施年 & 実施期間 & 平均温度 $\left({ }^{\circ} \mathrm{C}\right)$ & 平均湿度 $(\%)$ & 苗の由来 ${ }^{1)}$ & 立枯病菌数 ${ }^{2)}(\mathrm{CFU} / \mathrm{g}$ 乾土 $)$ \\
\hline 1 & 2016 年 & $10 / 17 \sim 11 / 1$ & 23.0 & 63.5 & ポット (1), (2) & $6.1 \times 10^{4}$ \\
2 & 2017 年 & $2 / 13 \sim 3 / 1$ & 22.3 & 83.1 & ポット (3) & $6.3 \times 10^{4}$ \\
3 & 2016 年 & $8 / 1 \sim 8 / 16$ & 30.9 & 67.8 & ポット (2) & $2.7 \times 10^{3}$ \\
\hline
\end{tabular}

1)ポット(1)は2015 年 11 月 12 日，(2)は2016年3月15 日, (3)は2016年 11 月 2 日にポットに種イモを植え付けて温室で育苗し，苗を 繰り返し採取した。

2) 立枯病菌接種区の培土中の立枯病菌数. CFU : colony-forming unit（コロニー形成単位）.
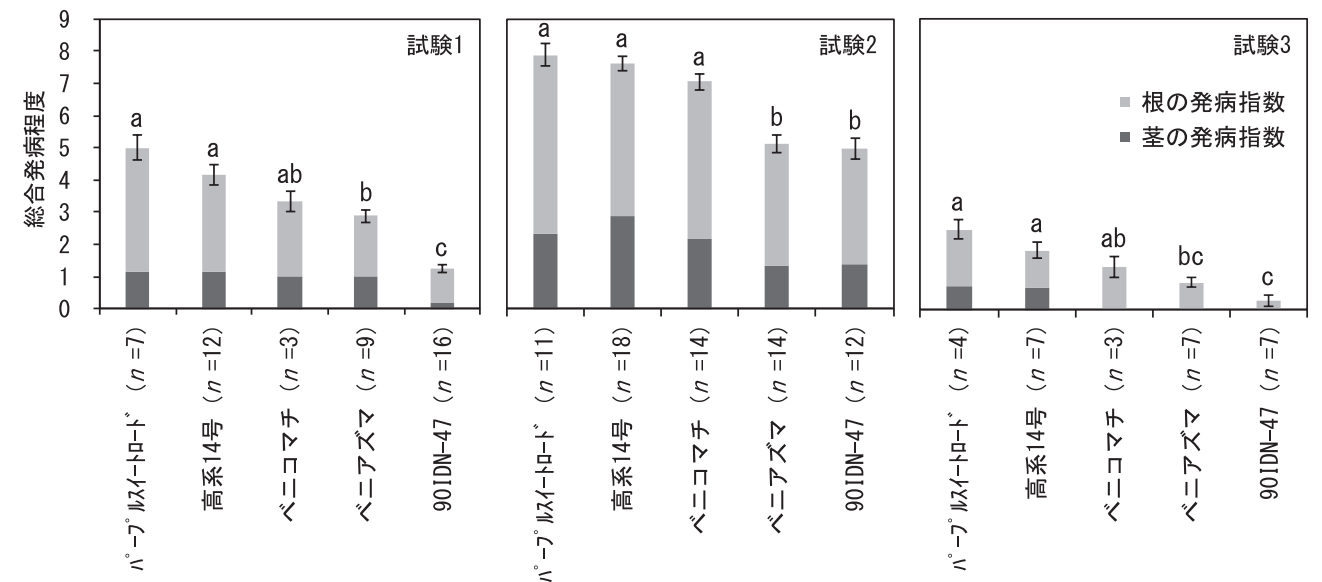

図 3. 室内検定法に抢けるサッマイモ 4 品種 1 系統の立枯病発病程度.

立枯病抵抗性程度が異なるサッマイモ 4 品種 1 系統, 「パープルスイートロード」(弱), 「高系 14 号」(弱)，「ベニコマチ」(やや弱)，「ベニアズマ」(やや強)，「90IDN-47」(強）を供試し，秋期 (試験 1), 冬期（試験 2), 夏期（試験 3）に室内抵抗性検定を行った。発病程度は，黒変・腐敗面 積に基づいて, 茎は 6 段階, 根は 7 段階の発病指数で評価し，それらを加算した総合発病程度を平 均值 \pm 標準䛊差 $(n=3 \sim 18)$ で示す．異なる英小文字を有する数值間は $5 \%$ 水準で有意差があるこ とを示す (Tukey-Kramer の HSD 検定).

田ら（2016）は，塊根組織円盤を立枯病菌懸濁液に浸し てバーミキュライトに埋設し, 塊根の発病から抵抗性を 評価する検定法に拈いて，バーミキュライトの含水量が 増加すると発病が高まり, 最大容水量の時に最も発病す ることを報告している。苗は塊根とは異なる反応を示す 可能性も考えられるが，バーミキュライトを培地として 放線菌を培養する際, バーミキュライトが乾燥しすぎる と菌の増殖が悪くなることがあるため (データ未掲載), 試験 2 に打けるバーミキュライトの水分条件は，放線菌 である立枯病菌にとって試験 1 よりも増殖しやすい環境 であり，その結果発病が高まった可能性も考えられる. 圃場土またはバーミキュライトを用いて検定を行う場合, それぞれに適した水分条件とその理由を明らかにするた めには更なる試験が必要である。

本試験では，抵抗性強の「90IDN-47」扣よびやや強の 「ベニアズマ」の総合発病程度は 5 程度の高い值を示した が，このよらな発病し易い条件下に拈いても，抵抗性弱 の「パープルスイートロード」,「高系 14 号」扎よび抵抗 性がやや弱の「ベニコマチ」の発病程度とは有意な差異 が認められた（図 3)。な物，固場検定に拈いて抵抗性弱 と評価された「高系 14 号」と「パープルスイートロー ド」では，苗を用いた本検定に拈いて茥と根の発病し易
さに違いが認められ,「高系 14 号」は茥が比較的発病し 易く,「パープルスイートロード」は根が発病し易い傾向 が認められた。

夏期に行った試験 3 は， $10^{3}$ 倍希釈の立枯病菌懸濁液 を接種源として用いたため，接種区培土の立枯病菌数は 試験 1 および 2 の約 1/23 となり（表 1 ）, その結果, 全品 種・系統とも, 試験 1 および 2 よりも発病が低くなった 可能性が考兄られる（図3）。このよらな発病しにくい条 件下に扣いても，抵抗性強の「90IDN-47」扣よびやや強 の「ベニアズマ」と，抵抗性弱の「パープルスイートロー ド」拉よび「高系 14 号」の発病程度の間には有意差が認 められた。「90IDN-47」は抵抗性やや弱の「ベニコマチ」 とも有意差が認められたが，「心゙ニアズマ」は「ベニコマ チ」とは有意差は認められなかった.

藏之内ら（2014）は，立枯病発生圃場で 2 ヶ月間栽培 したサッマイモの発病程度を, 茎扎よび細根, 塊根の病 斑数と曼の伸長状況に基づき 6 段階（1：無病徴～6: 枯 死）の発病指数で評価している. 発病程度の評価方法は 本試験と異なるが，藏之内ら（2014）が 9 年にわたり圃 場で行った抵抗性検定の結果（7または 9 年の平均值） と, 本試験で行った抵抗性検定（試験 1～3）の結果をそ れぞれ比較した。試験実施時の各種条件が異なる試験 1 
～3 の間では, 供試した 4 品種 1 系統の発病程度は異なっ てはいたが，いずれの場合も圃場での発病程度が高い品 種活ど室内検定でも発病して扣り, 圃場検定に拈ける発 病程度（平均值）と室内検定に打ける個体毎の総合発病 程度との間の積率相関係数は, 試験 1 は $r=0.8250$, 試験 2 は $r=0.7783$, 試験 3 は $r=0.8009$ であり, $0.1 \%$ 水準で 有意に高い相関が認められた。なお，3つの試験を比べ ると, 試験 1 の 4 品種 1 系統の総合発病程度（図 3）が, 圃場検定の発病程度に最も近い值を示した.

\section{3. 供試苗の形質と立枯病発病程度}

統計解析に十分な供試苗数のあった試験 1 （秋期に実 施）の「90IDN-47」，「高系 14 号」扣よび試験 2（冬期に 実施）の 4 品種 1 系統について, 苗の形質と発病程度と の関係を評価したところ，試験 1 の「90IDN-47」と「高 系 14 号」では，採取苗の茥の長さ（図 4), 節数拈よび 調整後の苗の茥の太さと総合発病程度との間に有意な相 関関係は認められなかった（試験 1 では土中埋没節数は 計測していない).

一方，発病し易い状況にあった試験 2 においては，抵 抗性強の「90IDN-47」では，採取苗の茎の長さと総合発 病程度との間に $5 \%$ 水準で有意な正の相関が認められた (図 $4 ; \rho=0.600$ ). また, 採取苗の節数と総合発病程度と
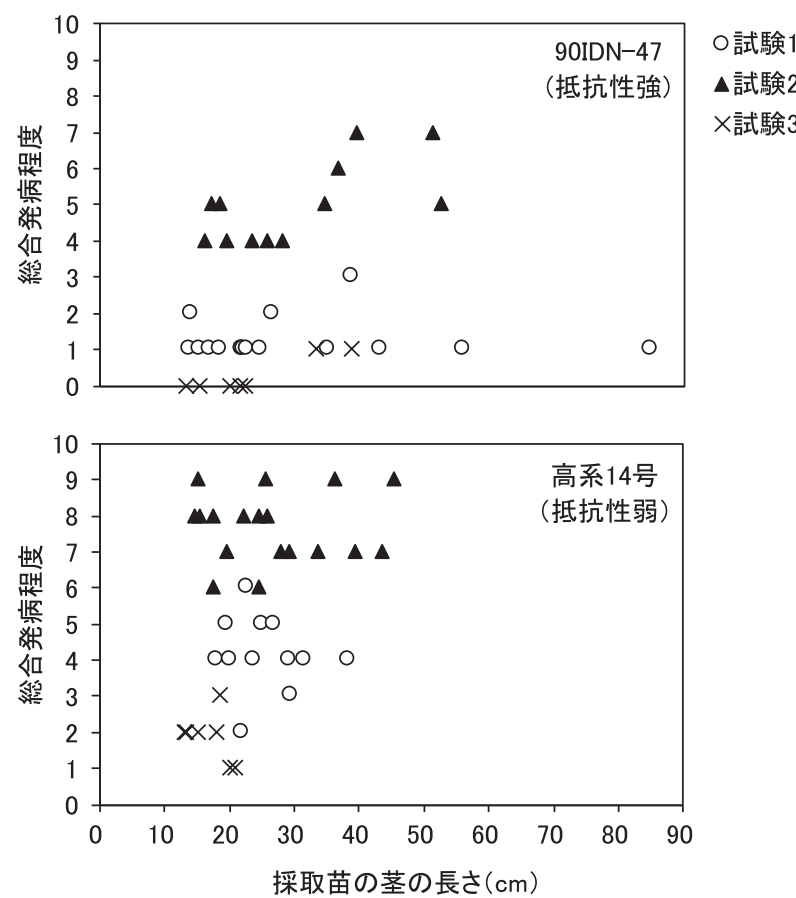

図 4. 室内検定法に括ける供試苗の長さと発病程度との関係. 立枯病抵抗性程度が異なるサッマイモ 1 品種 1 系統につい て, 秋期 (試験 1), 冬期（試験 2), 夏期（試験 3）に行っ た室内抵抗性検定の結果を示す。苗は, 採取時に茎の長さ を計測し， $33 \mathrm{~cm}$ 未満はそのまま， $33 \mathrm{~cm}$ 以上は茎頂基部 から $25 \mathrm{~cm}$ を切断して供試した。発病程度は, 黒变・腐敗 面積に基づいて茎は 6 段階, 根は 7 段階の発病指数で評価 し，それらを加算した総合発病程度を個体毎に示す。
の間にも $1 \%$ 水準で有意な正の相関が認められた（ $\rho=$ 0.715)。抵抗性やや強の「ベニアズマ」でも，採取苗の 長さと総合発病程度との間に $5 \%$ 水準で有意な正の相関 が認められた $(\rho=0.624)$.「ベニアズマ」では採取苗の 節数と総合発病程度との間には有意な相関関係は認めら れず，他の 3 品種（「ベニコマチ」，「高系 14 号」，「パー プルスイートロード」）の採取苗の長さおよび節数と総合 発病程度との間にも有意な相関関係は認められなかった が，生育の進んだ苗を用いる場合には，先端 $25 \mathrm{~cm}$ を切 断して供試するとしても，品種によっては発病が高まる 可能性のあることが示唆された.

試験 2 に打いて，「ベニアズマ」では土中埋没節数と総 合発病程度との間に $1 \%$ 水準で有意な負の相関が認めら れた $(\rho=-0.661)$. 本検定法では, 苗の植え付け後に地 際部に立枯病菌を接種するため, 埋没した茎の上位節か ら発根した根の基部が下位節の根よりも激しく発病する 傾向がある。そこで, 埋没節数が多いと発病程度が高く 評価される可能性を懸念したが，「ベニアズマ」以外の 3 品種 1 系統では，埋没節数と発病との間に有意な相関関 係は認められなかった。「ベニアズマ」では予想に反し埋 没節数が少ないと発病が高まる結果となったが，この原 因を解明するためには，更なる試験が必要である.

試験 2 に扣いて，4 品種 1 系統と夕, 調整した苗の菱 の太さと総合発病程度との間には有意な相関関係は認め られなかった。

\section{まとめ}

藏之内ら（2014）は國場試験において，立枯病の発生 には地温が大きく影響すること，および，年により発病 程度が変動しても品種・系統間でその高低が逆転するこ とは少ないことを報告している，本室内検定法では，地 温は $30 \pm 1{ }^{\circ} \mathrm{C}$ に一定に保たれているが，気温や湿度など 他の環境要因は制御されておらず，供試した 4 品種 1 系 統の発病程度は, 湿度条件が大きく異なった試験 1,2 間 で大きく変動した（図 3)。また，培土中の立枯病菌数に よっても発病程度は変動し（図 2, 図 3), 土畩中の立枯 病菌数が圃場での発病程度の变動の一因となっているこ との董付けが得られた。このように，室内検定に拈いて も試験実施時の条件変動により発病程度は変動したが, 圃場検定と同様に発病程度の高低が品種・系統間で逆転 することはなかった。したがって，本室内検定法に掞い ても，高野ら（2006）が提言したように抵抗性強の

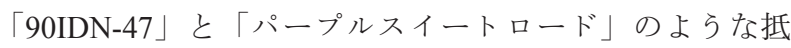
抗性弱の品種を標準品種・系統として毎回の試験に組み 入れることで，一年を通じて，供試系統の抵抗性評価が 可能であると考えられる. 3 回行った検定試験において, やや弱品種が弱品種およびやや強品種と, やや強品種が やや弱品種拈よび強系統と, 統計解析によって判別でき ない場合があった。しかし, 弱品種とやや強品種および 
強系統の間には常に有意な発病程度の差異が認められた ため，本室内検定法を用いて，やや強以上の抵抗性が期 待できる育成系統を簡易選抜することが可能であると考 えられる。なお, 供試する苗の種イモの植光付け時期や， 採取時の長さ, 節数の違いでも発病が変動する場合があっ たため, 1 回の試験には, 同じ時期に植え付けた種イモ から， $25 \mathrm{~cm}$ 前後のできるだけ戋場に植光付ける苗に近 い長さの苗を採って供試するのが望ましいと考兄られる.

これまでに考案された立枯病抵抗性室内検定法 (Moyer et al. 1984, 井内ら 2005, 高野ら 2006）では, 検定に要 する日数, 供試植物体の腐敗, 供試土壌の立枯病菌数が 不明, 灌水の労力などが問題点と考兄られた。本室内検 定法では, 苗を植兄付けてから 2 週間後に発病調査を行 らため，短期間での検定が可能である。また，培養した 立枯病菌を培土（バーミキュライト）に接種するため, 任意の病原菌数に拈ける発病程度の評価が可能である. 接種源とする菌体懸濁液から培地成分を取り除くことに より, 植え付けた苗が立枯病の症状以外で腐敗すること もなかった。また，栽培期間中は個々の重量を測定せず に，一部の遠沈管が浮いてくるのを目安にして一斉に同 量の水を補給するため, 水管理は容易である. 本法では, 培土の水分条件は同一にならず，灌水時に培土に吸水さ れず遠沈管内に一時的に溜まる水分量には個体により違 いが認められたが，この水分量の違いが立枯病発病の高 低に明らかに影響している様子は見られなかった。

井内ら（2005）の方法は $3 \mathrm{~cm}$ 程度の茎断片を用いるた め, 同一の温度, 湿度条件での試験が可能であり, 水管 理の必要もないため, より簡便に安定した抵抗性評価を 得られる可能性がある。しかし，戋場検定において抵抗 性弱と評価された「高系 14 号」と「パープルスイート ロード」では，苗を用いた本検定に打いて茥と根の発病 し易さに違いが認められて打り（図 3), 茎の病徴の反を 評価する井内ら（2005）の方法では，國場検定結果と評
価が異なる品種が生じる可能性も考えられる.

今後は本室内検定法を用いて他品種の抵抗性程度も評 価できるかどらか検証試験を行いたい.

\section{謝 辞}

本研究を行らにあたり, 九州沖縄農業研究センタ一業 務第 3 科員の上村政文氏, 福重伸隆氏, 三池徳近氏, 谷 門定氏, 德地伸彦氏, 松本一弥氏, 畠中幸一氏, 吉留克 彦氏, 吉田孝氏, 契約職員の松㟝あづさ氏, 井口美妃氏, 池田紘子氏にご協力をいただいた。ここに記して厚く感 謝の意を表する，な挔，本研究は，農林水産省「農林水 産業・食品産業科学技術研究推進事業」により遂行され たものである。

\section{引用文献}

Clark, C.A. and J.W. Moyer (1988) Compendium of sweet potato disease. The American Phytopathological Society, St. Paul, 6-9.

Clark, C.A. and S.W. Matthews (1987) Phytopathology 77: 14181423.

井内美砂 - 川村泰史 - 小巻克巳 (2005) 育種学研究 7: 45-49.

藏之内利和 - 高田明子 - 中村善行 - 田宮誠司 - 中谷 誠 - 熊谷 享・片山健二 (2014) 育種学研究 16: 147-150.

Locci, R. (1994) Eur. J. Plant Pathol. 100: 179-200.

Loria, R., R.A. Bukhalid, B.A. Fry and R.R. King (1997) Plant Dis. 81: 836-846.

Moyer, J.W., C.L. Campbell, E. Echandi and W.W. Collins (1984) Phytopathology 74: 494-497.

日本いも類研究会（2009）サッマイモ MiNi 白書 Ver. 3 [http:// www.jrt.gr.jp/smini/sm_index.html]

鈴井孝仁（1987）植物防疫 41: 307-311.

高野幸成・雨宮昭彦・猪野 誠（2006）関東東山病虫研報 53: 29-33.

吉田政博 - 西田智美 - 舩津丸貞信 - 岡田吉弘 (2016) 九病虫研 会報 62: 27-33. 